\title{
Total ocular akinesis: Miller Fisher or Guillain-Barré syndrome?
}

\section{Catkowity brak ruchomości gałek ocznych: zespół Millera Fishera czy zespół Guillaina-Barrégo?}

\author{
Kinga Rajska', Jacek Rożniecki², Piotr Loba³, Małgorzata Zielińska², Anna Broniarczyk-Loba \\ IZakład Patofizjologii Widzenia Obuocznego i Leczenia Zeza I Katedry Chorób Oczu, Uniwersytet Medyczny w Łodzi \\ ${ }^{2}$ Klinika Neurologii, Uniwersytet Medyczny w todzi \\ ${ }^{3}$ Klinika Chorób Oczu I Katedry Chorób Oczu, Uniwersytet Medyczny w todzi
}

Neurologia i Neurochirurgia Polska 2011; 45, 3: 297-300

\begin{abstract}
Total, bilateral ophthalmoplegia is very rare. More than $50 \%$ of cases are Miller Fisher (MFS) and Guillain-Barré (GBS) syndromes. There is a correlation of MFS with anti-GQ1b antibodies. High levels of GQ1b gangliosides are found in myelin sheathes of cranial nerves supplying the extraocular muscles. This may explain the association of anti-GQ1b antibodies with ophthalmoplegia. Anti-GQ1b were also found in cases of GBS accompanied by ophthalmoplegia, atypical MFS (MFS without ataxia), MFS/GBS overlap syndromes and Bickerstaff brainstem encephalitis. This has led some authors to classify them as 'anti-GQ1b syndromes'.

In this article we describe a diagnostically difficult case of a patient with a very rare, total bilateral paralysis of all ocular muscles, accompanied by bilateral ptosis, diminished tendon reflexes of upper extremities, paresis and hypoesthesia of the left upper extremity.
\end{abstract}

Key words: ophthalmoplegia, Miller Fisher syndrome, Guillain-Barré syndrome.

\section{Introduction}

Total, bilateral ophthalmoplegia is very rare. According to Keane, it constitutes no more than 2/1000 cases admitted to neurology and neurosurgery departments [1]. Among these, Miller Fisher (MFS) and Guillain-

\section{Streszczenie}

Całkowita, obustronna oftalmoplegia występuje bardzo rzadko, a ponad połowę przypadków stanowią zespół Millera Fishera (MFS) i zespół Guillaina-Barrégo (GBS). Istnieje korelacja MFS z przeciwciałami anty-GQ1b przeciwko gangliozydom, których duże stężenie występuje w osłonkach mielinowych nerwów gałkoruchowych, co może tłumaczyć ich związek z oftalmoplegią. Obecność przeciwciał anty-GQ1b stwierdzano również w przypadkach GBS z towarzyszącą oftalmoplegią, atypowym MFS (MFS bez ataksji), zespołach nakładania MFS/GBS, a także zapaleniu pnia mózgu Bickerstaffa, co skłania niektórych autorów do sklasyfikowania tych jednostek jako tzw. zespołów z przeciwciałami anty-GQ1b.

W artykule opisano trudny diagnostycznie przypadek pacjentki z bardzo rzadkim, obustronnym porażeniem wszystkich mięśni gałkoruchowych i towarzyszącym opadnięciem powiek, osłabieniem odruchów ścięgnistych kończyn górnych oraz niedowładem i niedoczulicą lewej kończyny górnej.

Słowa kluczowe: oftalmoplegia, zespół Millera Fishera, zespół Guillaina-Barrégo.

Barré (GBS) syndromes make up over $50 \%$ of cases. Other, less common causes are midbrain infarction, myasthenia, pituitary apoplexy, skull base metastasis, phenytoin intoxication, mucormycosis and botulism.

In 1956, Fisher was the first to describe a syndrome with a triad of symptoms: ataxia, ophthalmoplegia and

Correspondence address: dr Kinga Rajska, Zakład Patofizjologii Widzenia Obuocznego i Leczenia Zeza I Katedry Chorób Oczu, Uniwersytet Medyczny w todzi, ul. Kopcińskiego 22,90-153 Łódź, Polska, e-mail: kinja@02.pl

Received: 10.06.2010; accepted: 24.01.2011 
areflexia. He proposed to classify it as a rare variant of GBS [2]. The disease is commonly preceded by an infection and its course ends with a full recovery after few weeks or months [3-6]. Between 15\% and $20 \%$ of patients experience moderate residual deficits. There is a correlation of MFS with anti-ganglioside GQ1b (antiGQ1b) antibodies, which are produced in a cross-reaction to the antigens of certain pathogens such as Campylobacter jejuni [7-9]. Antibodies to glycolipids are observed in $81-90 \%$ of all MFS patients during the acute phase of the illness $[10,11]$. High concentrations of GQ1b gangliosides are found in myelin sheaths of cranial nerves that supply the extraocular muscles. This fact may explain the association of anti-GQ1b antibodies with ophthalmoplegia. Anti-GQ1b were also found in cases of GBS accompanied by ophthalmoplegia, atypical MFS (MFS without ataxia), MFS/GBS overlap syndromes and Bickerstaff brainstem encephalitis (BBE), in which the clinical triad of MFS is associated with disturbances of consciousness and pyramidal tract dysfunction.

The association of all these nosologically different disorders with anti-GQ1b antibodies indicates the common pathogenesis and leads some authors to classify MFS, GBS with ophthalmoplegia, MFS/GBS overlap syndromes, BBE and atypical MFS as 'anti-GQ1b syndromes' $[12,13]$.

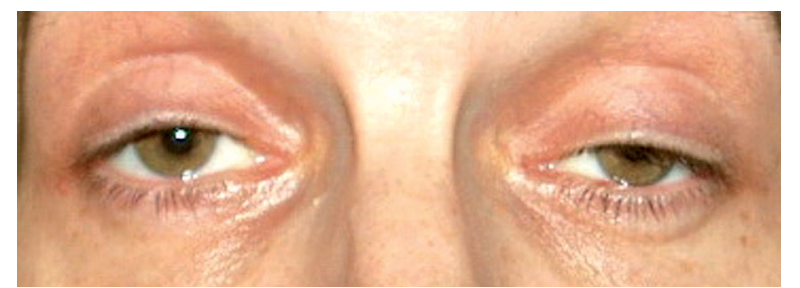

Fig. 1. Bilateral ptosis and left-sided hypotropia

\section{Case report}

A 37-year-old female was referred to the Neurology Department, Medical University of Lodz with ocular motility disorder and paresis of the left upper extremity. Neurological examination on the day of admission revealed complete, bilateral ocular akinesis, ptosis, more eminent on the left side, paresis and hypoesthesia of the left hand and diminished tendon reflexes of the upper extremities.

The patient had been hospitalized in the Surgery Department 2 months before due to a suspected gastric tumour. The main complaints included abdominal pain, diarrhoea and weight loss of over $15 \mathrm{~kg}$ in a period of one month. Gastric malignancy was excluded. Three weeks after the onset of the gastrointestinal symptoms left hand paresis and horizontal diplopia occurred.

On the second day of her stay at the Neurology Department, the patient was referred for consultation at the Department of Binocular Vision Pathophysiology and Strabismus at the Medical University of Lodz. Orthoptic examination revealed bilateral ptosis (slightly more marked on the left side) and left-sided hypotropia (with right eye fixating) (Fig. 1). The existing vertical diplopia was alleviated by the introduction of the $8 \Delta$ base up prism. Ductions were measured on a major amblyoscope. There was a minimal vertical motility of the right globe with no horizontal movement. The left globe was completely akinetic (Fig. 2). The best corrected visual acuity was: left eye 0.7 , right eye 0.8 . Surprisingly when the patient adopted a specific head posture the acuity improved to: left eye 0.9 , right eye 1.0.

On additional testing, elevated platelets were found without any other deviations in blood count. Blood coagulation, glucose level and thyroid hormones were normal. Serum antibodies against human immunodefi-
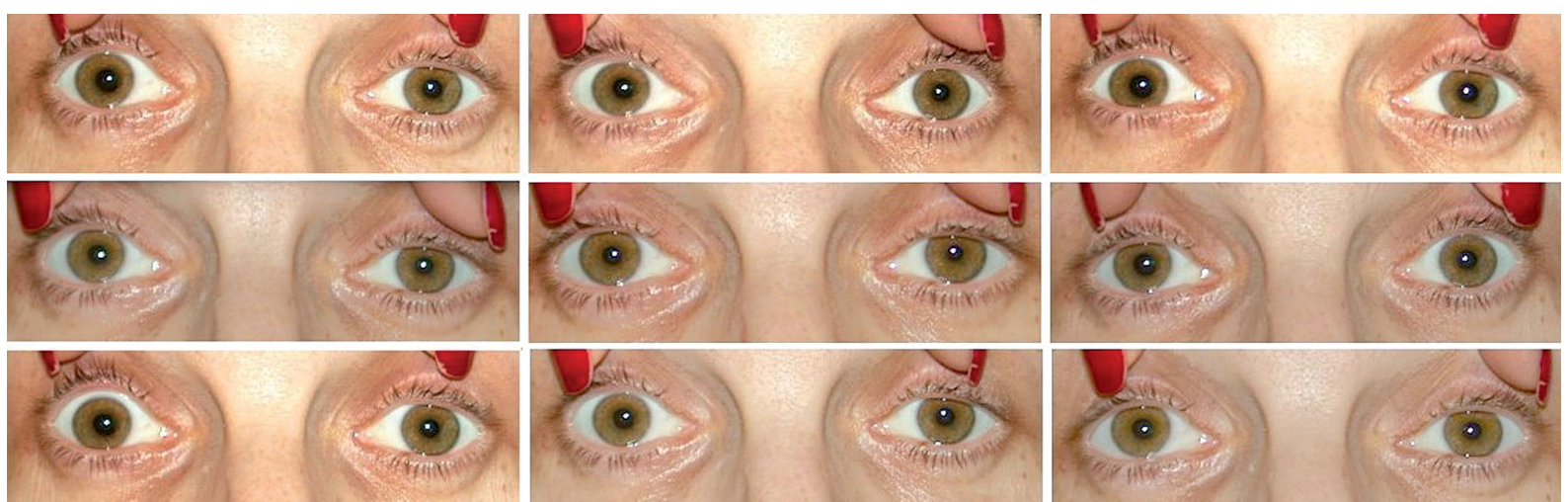

Fig. 2. Ocular motility in nine gaze directions on the second day of hospitalization 
ciency virus (anti-HIV), hepatitis $\mathrm{C}$ virus (anti-HCV) and hepatitis $\mathrm{B}$ surface antigen ( $\mathrm{HBsAg}$ ) were negative. The level of acetylcholine receptor antibodies was $0.33 \mathrm{nmol} / \mathrm{l}$ (positive levels over $0.4 \mathrm{nmol} / \mathrm{l}$ ). Cerebrospinal fluid examination showed normal cell count, elevated immunoglobulin $G(\operatorname{IgG})$ index of 0.72 (normal range up to 0.7 ), and protein level was raised at $144 \mathrm{mg} /$ $\mathrm{dl}$ (normal range up to $45 \mathrm{mg} / \mathrm{dl}$ ). Neuroimmunological Western blot tests were performed 5 months after the discharge and anti-GQ1b, anti-GM1 and antiGD1b serum IgG and IgM antibodies were negative, although the patient still had neurological symptoms.

The nerve conduction study revealed high graded axonal-demyelinating disruption of motor and sensory fibres of the left median and ulnar nerves and slight axonal-demyelinating disruption of motor fibres of the right median nerve and sensory fibres of the right ulnar nerve. The F-wave was absent after stimulation of the motor fibres of the left ulnar and median nerves, but the parameters of the F-wave were normal after stimulation of the motor fibres of the right ulnar and median nerves as well as the left tibial and peroneal nerves. The test with edrophonium was negative.
Brain magnetic resonance imaging (MRI) revealed a solitary hyperintense lesion (4 $\mathrm{mm}$ in diameter) in the left semiovale centre and a polyp-shaped lesion in the left maxillary sinus.

Due to suspected coeliac disease a duodenal biopsy was performed and it revealed atrophy of the intestinal villi. Anti-endomysial and anti-transglutaminase antibodies were negative. The gastric wall biopsy showed a chronic ulcer with high-grade glandular dysplasia and no signs of Helicobacter pylori.

The patient underwent five cycles of plasmapheresis. During the course of treatment ocular motility gradually improved (Table 1, Fig. 3). Moreover, the paretic symptoms of left upper extremity receded and the patient was discharged in a stable condition.

The subsequent orthoptic examination, 3 months after the first investigation, revealed slight right-sided ptosis, reduced ptosis on the left side, and right-sided hypertropia (the patient took up fixation with her left eye). Vertical and horizontal diplopia was present. It could be alleviated with an $8 \Delta$ prism in the axis of $255^{\circ}$ placed in front of the right eye.

Table 1. The dynamics of ocular motility disturbances measured on a major amblyoscope in a range of $30^{\circ}$ vertically and $45^{\circ}$ horizontally

\begin{tabular}{|c|c|c|c|c|c|c|c|c|}
\hline & \multicolumn{2}{|c|}{ On admission } & \multicolumn{2}{|c|}{$\begin{array}{r}\text { After the first } \\
\text { plasmapheresis }\end{array}$} & \multicolumn{2}{|c|}{$\begin{array}{c}\text { After the fifth } \\
\text { plasmapheresis }\end{array}$} & \multicolumn{2}{|c|}{ After 3 months } \\
\hline & $\begin{array}{l}\text { Right } \\
\text { globe }\end{array}$ & $\begin{array}{l}\text { Left } \\
\text { globe }\end{array}$ & $\begin{array}{l}\text { Right } \\
\text { globe }\end{array}$ & $\begin{array}{l}\text { Left } \\
\text { globe }\end{array}$ & $\begin{array}{l}\text { Right } \\
\text { globe }\end{array}$ & $\begin{array}{l}\text { Left } \\
\text { globe }\end{array}$ & $\begin{array}{l}\text { Right } \\
\text { globe }\end{array}$ & $\begin{array}{l}\text { Left } \\
\text { globe }\end{array}$ \\
\hline Sursumduction & $5^{\circ}$ & $0^{\circ}$ & $10^{\circ}$ & $4^{\circ}$ & $25^{\circ}$ & $20^{\circ}$ & $30^{\circ}$ & $27^{\circ}$ \\
\hline Infraduction & $3^{\circ}$ & $0^{\circ}$ & $10^{\circ}$ & $4^{\circ}$ & $30^{\circ}$ & $27^{\circ}$ & $27^{\circ}$ & $30^{\circ}$ \\
\hline Adduction & $0^{\circ}$ & $0^{\circ}$ & $13^{\circ}$ & $11^{\circ}$ & $25^{\circ}$ & $22^{\circ}$ & $45^{\circ}$ & $45^{\circ}$ \\
\hline Abduction & $0^{\circ}$ & $0^{\circ}$ & $-3^{\circ}$ & $-2^{\circ}$ & $-30^{\circ}$ & $-19^{\circ}$ & $-45^{\circ}$ & $-25^{\circ}$ \\
\hline
\end{tabular}
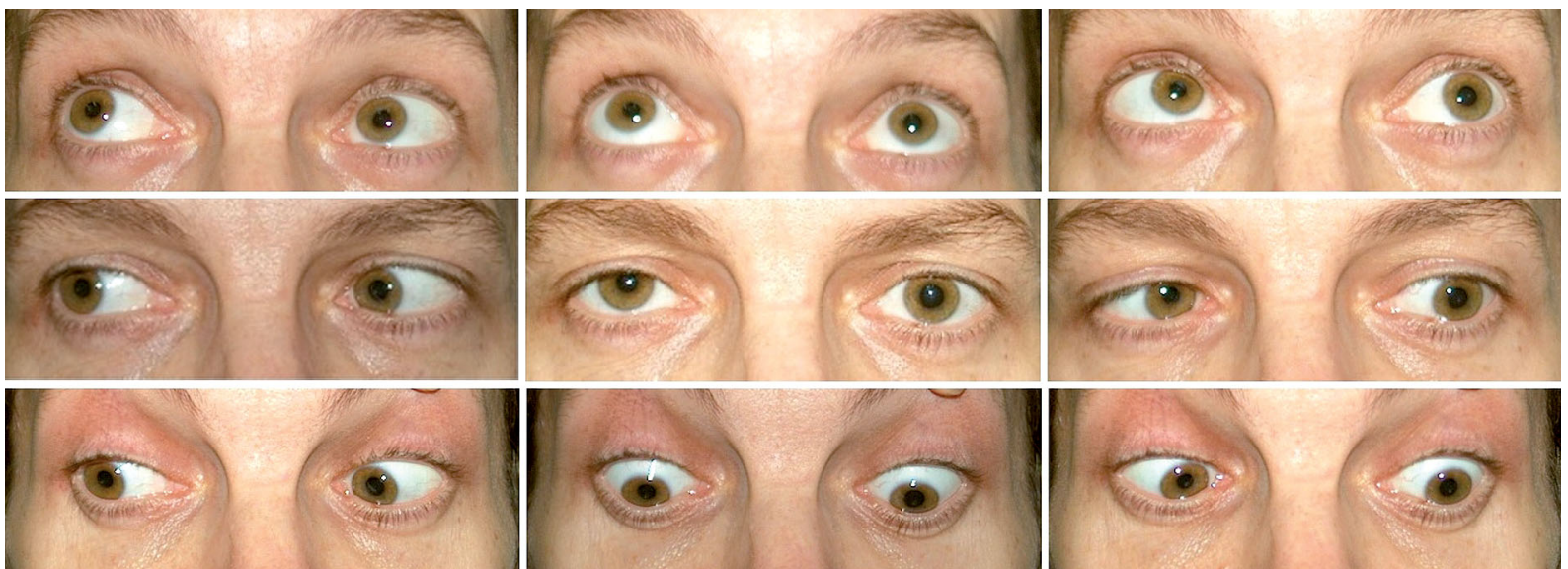

Fig. 3. Ocular motility in nine gaze directions after the fifth plasmapheresis 
Neurological examination 3 months after discharge revealed further improvement of ocular rotations, with the presence of diplopia, especially in left gaze, and a slight asymmetry of the eye fissures (the right one was narrower). The muscle force of the upper extremities was asymmetrical - the left upper extremity was weaker and was estimated at $4 / 5$ on the Lovet scale.

Five months after discharge, nerve conduction assessment was performed. In comparison to the previous study it had not changed significantly. Due to intractable diplopia prism glasses were prescribed. The patient remained under long-term follow-up in the neurological and strabismological outpatient clinic.

\section{Discussion}

In the presented case, the dominating clinical symptom was complete ocular akinesis accompanied by ptosis, paresis and hypoesthesia of the left hand and diminished tendon reflexes of the upper extremities.

Negative edrophonium test and the non-elevated levels of acetylcholine receptor antibodies argued against myasthenia gravis. Paraneoplastic myasthenic syndrome associated with gastric tumour was excluded in biopsy.

Duodenal biopsy revealed atrophy of the intestinal villi, but anti-endomysial and anti-transglutaminase antibodies were negative and argued against coeliac disease.

Nerve conduction study and albumino-cytological dissociation in the cerebrospinal fluid suggested an inflammatory, demyelinating disease.

The abdominal complaints preceding the neurological symptoms for a few weeks could have had an infectious background, not related to ulceration. This might support the hypothesis of inflammatory origin of the disease. In typical MFS, ophthalmoplegia and areflexia are accompanied by ataxia, not observed in this case. This fact suggested a diagnosis of atypical MFS. However, the coexisting sensorimotor disturbances of the left upper extremity supported the diagnosis of GBS with ophthalmoplegia. On the other hand, the asymmetry of these signs is rather against it. Negative anti-GQ1b serum antibodies do not exclude MFS or GBS, as they occur in the majority but not in all patients. The constellation of signs and symptoms in this case makes the most probable diagnosis MFS/GBS overlap syndrome.

\section{References}

1. Keane J.R. Bilateral ocular paralysis: analysis of 31 inpatients. Arch Neurol 2007; 64: 178-180.

2. Fisher M. An unusual variant of acute idiopathic polyneuritis: syndrome of ophthalmoplegia, ataxia and areflexia. $N$ Engl J Med 1956; 25 5: 57-65.

3. Wertheim M.S., Benzimra J.D., Jadresic L.P., et al. Ocular presentation of pediatric Miller-Fisher syndrome. J Pediatr Ophthalmol Strabismus 2008; 45: 245-246.

4. Lo Y.L. Clinical and immunological spectrum of the Miller Fisher syndrome. Muscle Nerve 2007; 36: 615-627.

5. Santra G., Datta A.K. Miller Fisher syndrome - an uncommon clinical presentation. J Assoc Physicians India 2008 ; 56: 898-900.

6. Bilińska M., Koszewicz M. Miller Fisher syndrome with pronounced difficulty in swallowing and speaking. Adv Clin Exp Med 2004; 13: 315-319.

7. San-Juan O.D., Martinez Herrera J.F., Garcia J.M., et al. Miller Fisher syndrome: 10 years' experience in a third-level center. Eur Neurol 2009; 62: 149-154.

8. Mori M., Kuwabara S., Fukutake T., et al. Plasmapheresis and Miller Fisher syndrome: analysis of 50 consecutive cases. J Neurol Neurosurg Psychiatry 2002; 72: 680.

9. Becker U., Gahn G., Reichmann H., et al. Miller Fisher syndrome. Case report and review with discussion of differential diagnosis and nosology. Nervenarzt 2006; 77: 716-721.

10. Nishimoto Y. Usefulness of anti GQ1b IgG antibody testing in Fisher syndrome compared with cerebrospinal fluid examination. J Neuroimmunol 2004; 148: 200-205.

11. Chiba A. Serum IgG antibody to ganglioside GQ1b is a possible marker of Miller Fisher syndrome. Ann Neurol 1992; 31: 677-679.

12. Saul R.F. Neuro-ophthalmology and the anti-GQ1b antibody syndromes. Curr Neurol Neurosci Rev 2009; 9: 379-383.

13. Ogawara K., Kuwabara S., Nobuhiro Y. Fisher syndrome or Bickerstaff brainstem encephalitis? Anti-GQ1b IgG antibody syndrome involving both the peripheral and central nervous system. Muscle Nerve 2002; 26: 845-849. 